Cite as: Thalluri, J., \& Penman, J. (2016). To flip a class or not to flip a class: That is the question. Proceedings of Informing Science \& IT Education Conference (I ${ }^{n}$ SITE) 2016, 147-157. Retrieved from

http://www.informingscience.org/Publications/3414

\title{
To Flip a Class or Not to Flip a Class: That is the Question
}

\author{
Jyothi Thalluri \\ University of South Australia, \\ Adelaide, SA, Australia
}

jyothi.thalluri@unisa.edu.au

\author{
Joy Penman \\ University of South Australia, \\ Whyalla, SA, Australia
}

joy.penman@unisa.edu.au

\begin{abstract}
The flipped classroom is one of the recent innovations applied in teaching science concepts to nursing students. It is thought that a more engaging and meaningful learning environment is created, but how exactly this is achieved in flipped classroom is unclear.

The aims of this paper are to describe how a flipped classroom was effectively created for beginning off-campus nursing students studying the course Human Body, and to determine its impact on the learning experience of these students.

Survey methodology was used to evaluate students' perceptions about flipped classroom. A 15item questionnaire was administered to participants at the conclusion of the course. They were requested to rate or complete thirteen statements on a Likert scale relating to their learning experience and respond to two open-ended questions on what they liked most about the class and areas for improvement.

Forty-one ( $\mathrm{n}=41)$ students completed the post-flipped classroom survey, out of a total of 174 offcampus students for a $24 \%$ response rate. Though constrained with poor response, this study illustrated that the flipped classroom was a feasible learning and teaching approach for off-campus nursing students. For various reasons, $84 \%$ of respondents preferred the flipped classroom and $85 \%$ recommended it for future students.
\end{abstract}

Keywords: Flipped classroom, Off-campus, Nursing students, Teaching sciences

\section{Introduction}

The contemporary emphasis in the introduction of various teaching approaches and formats has been on the optimal engagement of students while providing flexibility in their learning. It is important that students are motivated to act on their learning needs, engaged with content, peers, and

Material published as part of this publication, either on-line or in print, is copyrighted by the Informing Science Institute. Permission to make digital or paper copy of part or all of these works for personal or classroom use is granted without fee provided that the copies are not made or distributed for profit or commercial advantage AND that copies 1) bear this notice in full and 2) give the full citation on the first page. It is permissible to abstract these works so long as credit is given. To copy in all other cases or to republish or to post on a server or to redistribute to lists requires specific permission and payment of a fee. Contact Publisher@,InformingScience.org to request redistribution permission. staff, and honed to become independent learners. This engagement is a challenge to achieve for off-campus students.

For many years, distance education and flexible delivery has made university study available to individuals who may have very limited access to a university. Flexibility is one of the major reasons off-campus study has been successful. 
Students determine when and where it suits them to engage with the content, other students, and the teacher. They determine their own timetable, study load, and pace of study. Moreover, students do not need to relocate away from home, lose connections with family and friends, venture into unfamiliar environment, and/or find new job/s and social life. Importantly, studying offcampus is less expensive in comparison to on-campus study. This flexibility of distance education allows for the university participation of heterogeneous students, but at the same time, necessitating creative strategies to assist off-campus students achieve academic success.

While off-campus study has advantages, students of distance education may feel at a disadvantage in some aspects of their study. For instance, students may experience restricted access and limited engagement to staff and fellow students. There may be a limited range of resources available at their disposal, less opportunity to attend workshops and events at campuses, and fewer choices of courses and in some cases even programs. Some of these disadvantages in studying externally are abated by communication capabilities to cross the distance and enhance learning and teaching. Communications between the staff and students, and between peers, have dramatically improved with the advent of podcasts/vodcasts, videoconferencing, discussion pages, virtual classrooms, and social media (Penman \& Ellis, 2008; Thalluri \& Penman, 2015a). These have made possible greater interaction, allowing lecturers and experts who are not able to be physically present to deliver talks and presentations to engage with students. These technological advances provide some approximation of the face-to-face teaching and learning interaction when that is not possible.

The flipped classroom is one of the recent 'innovations' applied in higher education. The F-L-I$\mathrm{P}^{\text {TM }}$ schema developed by the Flipped Learning Network and Pearson's School Achievement Services (Hamdan, McKnight, McKnight \& Arfstrom, 2013) has four components: flexible environment, learning culture, intentional content and professional educators, and support for student's engagement in flipped learning. In theory, the effective use of flipped classroom could transform traditional models of delivering higher education both on campus and externally, impacting positively on the overall academic experience of students and on learning outcomes. Chen, Wang, Kinshuk and Chen (2014) contend that the flipped classroom is under-utilised and underinvestigated, but has nevertheless been used to varying extents and through different formats with increasing expectations. What exactly is achieved in flipped classroom is not clear, and therefore this is the central question of this study.

Very recently, the flipped classroom was used in teaching some aspects of a science course to external nursing students enrolled in a South Australian university. This approach enabled students to access pre-recorded lectures and relevant resources before the flipped lectures, which were designed to consolidate learning by working through case scenarios. Our paper aims to describe how the flipped classroom was created for beginning external nursing students studying the course Human Body, and determine students' perceptions of the same.

\section{Background}

A flexible learning environment has been defined as accessing education in a way that is responsive in pace, place, and/or mode of delivery (Lee, 2007). This type of learning environment suits students of diverse and non-traditional study patterns and academic backgrounds, who collectively need a range of choices and options for where, when, and what they study. It is also particularly important for students studying through distance education. New and appropriate information technologies underpin a flexible learning environment and the University's infrastructure is designed to maximise this. Higher education has been transformed over the last three decades by the implementation of various forms of eLearning, as shown by a study into its effects (Singh, O'Donoghue, \& Worton, 2005). For one, it has changed the range of 'normal' university learning contexts and academic roles. It has also changed the reach of an institution, bringing many bene- 
fits including giving students a range of lifelong learning skills. Buzzetto-More (2008) summarises other benefits including the following: improved instruction and course management; numerous pedagogical advantages for learners (Kandies \& Stern, 1999); improved students' overall learning experience (Wernet, Olliges, \& Delicath, 2000); and a positive effect on student learning and skill development (Sanders \& Morrison-Shetlar, 2002).

E-learning, which has become an important component of tertiary teaching and learning, has undergone three distinct phases over time (Connolly \& Stansfield, 2007): first, the passive use of the Internet where traditional materials were simply repurposed to an online format; second, transition to higher band-widths, rich streaming media, increased resources, and the move to create virtual learning environments that incorporated access to course materials, communications, and student services; and, third, incorporation of greater collaboration, socialization, project based learning, and reflective practices, through such tools as e-portfolios, wikis, blogs, social bookmarking and networking, and online simulations.

The University of South Australia has been involved in distance education and flexible delivery for many years. Through its Learning and Teaching Unit, students can draw on services and resources to enhance their university experience (UniSA, 2015). The unit supports university aspiration by engaging with students through the provision of web-based resources, amongst other aids. Guided by UniSA's Digital Learning Strategy, the Learnonline Unit provides an integrated suite of software applications used to deliver quality technology-enhanced learning, while simultaneously facilitating Learnonline development, use, and future enhancements. The new technologies were created to enhance the learning experience of all students, especially off-campus students who encounter the greatest obstacles to university engagement. In response to student input, the focus of learnonline now includes flexible delivery of educational resources such as online topic notes/objectives, lecture notes, vodcast/podcast, discussion board, online quizzes, YouTube videos, and additional resources. These enhancements are aimed at achieving studentcentred and resource-based learning (Ramsden, 2003), providing students greater control over their learning, extending skills at independent learning, and reducing access barriers (Jung, 2001).

The notion of a student-centred classroom can be extended to online courses (Berner, 2004). In order to achieve student-centred online learning, the pedagogical background of online courses must be considered and appropriate staff development in successful online teaching provided. Just transferring on-campus course content to an online environment is unlikely to work - it is necessary to transform the course, with the lecturer becoming a facilitator or monitor of student interactions, which should have appropriate structure (Cayetano-Penman \& Ellis, 2007). Technology-based teaching can be supported by the engagement theory. This means that students are meaningfully engaged in learning activities through peer and lecturer interaction and worthwhile tasks (Kearsley \& Shneiderman, 1998), which brings us to the topic of flipping the classroom.

By moving the content outside of class and conducting flipped lectures, where students are provided with engaging, interactive, and motivating activities that examine their understanding about the subject matter, it is thought that a more dynamic and meaningful learning environment is created. Proposed by Bergmann and Sams (2012), flipping or inverting the classroom provides students with flexibility in learning. Students have the option to learn from a wide range of resources and determine their own pace of learning (Chen et al., 2014). The concept of flipped classroom refers to those learning situations outside the class and subsequent discussion of the learning that transpired inside the class (Baker, 2012; Barrett, 2012). Hamdan et al., (2013) assert that the schema achieved by a flipped classroom include flexible environment, learning culture, intentional content and professional educators, and support for student's engagement in flipped learning.

The motivations underpinning the flipped classroom, especially in higher education, have evolved. Changes in students' demographic characteristics and flexibility needs necessitate 
changes in course delivery. A case in point is the reduced contact time with students, requiring the optimisation of face to face contact time. The advancement and proliferation of high quality materials from various sources, especially online, has allowed students access to a range of resources, such as podcasts, online readings, and quizzes, at any location and time. Academics use the time to engage with students on their learning of content rather than developing and presenting their materials and resources via traditional lectures, thus allowing them to create high quality, flexible, collaborative, and active educational platforms for students (Educause Learning Initiative, 2012). In a flipped classroom, academics facilitate and guide students in order to reach higher orders of thinking such as reflecting, analysing, and evaluating (See \& Conry, 2014). In flipping the classroom, it is possible to provide students the knowledge and skills to teach themselves to learn, and thus they become independent learners.

\section{The Flipped Classroom}

Thalluri and Penman (2015b) utilised the flipped classroom as a learning and teaching approach in teaching a science course to both on- and off-campus nursing students. The flipping of the classroom applied to off-campus students is the focus of this paper.

The course that was flipped had a unit value of 4.5, initially taught with lectures ( 3 hours), and tutorial/practical ( 2 hours) per week during the second study period of the year (UniSA Course Information, 2015). The course content was divided into nine topics. Out of the nine lecture topics, four were flipped. The topics that were flipped included body organisation, cardiovascular system, central nervous system, and endocrine system. The rest of the topics, namely, chemistry, cells and tissues, blood, respiratory system, and lymphatic system, were taught via traditional lectures. This course was offered online to off-campus students.

For the flipped classes, pre-recorded lectures were made available to students prior to flipped lectures (online recorded lectures). Students were also provided with readings, YouTube videos, and other online resources. The pre-recorded lectures varied in length from 15 minutes to 35 minutes (maximum), which totalled on average 1.5 hours/week. All pre-recorded lecture recordings were deliberately broken down to short and concept-based lectures that were made available at the start of the study period.

The pre-lecture recordings covered mainly physiological concepts. Students were directed to the parts of anatomy they need to know to understand the physiological concepts. They were expected to learn and/or revise their understanding of anatomy on their own. Self-assessment quizzes that consisted of multiple choice questions were also made available for students to check their understanding of the topic. Students were expected to complete these quizzes prior to attending flipped lectures. The lecturer was able to check how many students attempted the quiz and the average mark for the topic. She was able to view which conceptual questions were difficult for students. These directed her to areas to focus on during the flipped lecture. The academic assumed tutor or facilitator roles during the flipped class.

Similar to on-campus students, off-campus students viewed and listened to the pre-recorded lectures prior to listening to the flipped lecture. During the flipped lecture, students constructed new understandings of the topic, applied their new knowledge to the case study, and provided answers to questions given to them. There was no new material introduced in the flipped lecture. Instead this time was used to clarify concepts the students had difficulty with and also put content into context using the case scenarios. Off-campus students viewed the questions/activities the lecturer posed in real time. They could answer with the class if they wish, and if they were not able to answer, they could find the answers and check if their answers were correct and listen to the lecturer for the explanation of the correct and wrong answers. These flipped lectures were recorded as well for the benefit of those who could not attend. 


\section{Methodology}

All off-campus students enrolled in the course were invited to participate in the survey. In order to preserve anonymity and confidentiality, names were not required. Online completion and submission of the questionnaire was taken as consent. Students had the option to not participate in the evaluations. The University's Ethics Committee approved this study.

Prior to flipping the classroom, a pre-flip survey consisting of eighteen (18) open-ended and closed questions was conducted to determine the following: students' demographic data, fluency in the English language, educational background, exposure to science, knowledge and experience of the flipped classroom, and propensity for preparation before lectures.

A 15-item post-flip questionnaire was administered to participants at the conclusion of the course. They were requested to rate or complete thirteen statements on a Likert scale relating to their learning experience and respond to two open-ended questions on what they liked most about the class and areas for improvement. Descriptive and frequency analyses were performed. Data analysis consisted of the frequency of responses or proportion of respondents in percentage form.

\section{Results}

Of the 174 off-campus students, 132 completed the pre-flip survey. English is the first language of the majority of students $(83 \%)$. The majority of students $(96 \%)$ were domestic students and were mature-aged students $(88.6 \%)$. The percentage of students who were the first in the family to go to university was $43.5 \%$. The majority (97\%) were not of Aboriginal or Torres Strait Islander origin.

Furthermore, it was found that the many students had no to little $(78.7 \%)$ science background. The majority had no knowledge about flipped classroom (80.8\%) and had no flipped classroom experience $(90.2 \%)$. It was found also that students prepared most of the time (43.3\%), sometimes $(31.5 \%)$, and always $16.2 \%$ before attending lectures.

Forty-one ( $\mathrm{n}=41)$ students completed the post-flipped classroom survey, out of a total of 174 offcampus students for a $24 \%$ response rate. Results showed that the approach had a $46 \%$ excellent rating. Students agreed $(73 \%)$ that it was easier to understand the content in utilising the flipped classroom. The majority (84\%) preferred the flipped classroom because they were able to access pre-recorded lectures, apply and test their knowledge, and clarify difficult concepts before the class. Thus $85 \%$ of those who responded recommended studying sciences in this manner.

The following graphs capture visually students' perceptions about this learning and teaching approach. The Figure 1 shows the appraisal of the flipped classroom by the students who responded to the post-flip survey, in which $34.15 \%$ thought the flipped classroom was good, and $46.34 \%$ thought it was excellent. Only $2.44 \%$ thought it was bad or very bad.

Figure 2 depicts the preference of flipped lectures versus traditional lectures by students, as well as students' recommended approach for future students. The majority preferred the flipped lecture style $(84.21 \%)$ and recommended it for future students $(85 \%)$.

There were several and varied reasons why the students liked the approach. Figure 3 demonstrates that the flipped classroom style made it easier to understand the course content $(73.17 \%)$, while Figure 4 shows that students perceived it as assisting them in learning the course content (60.98\% chose better and $21.95 \%$ chose much better than traditional lectures). There were other reasons why the flipped classroom was popular amongst the students and these are summarised in Figure 5. 


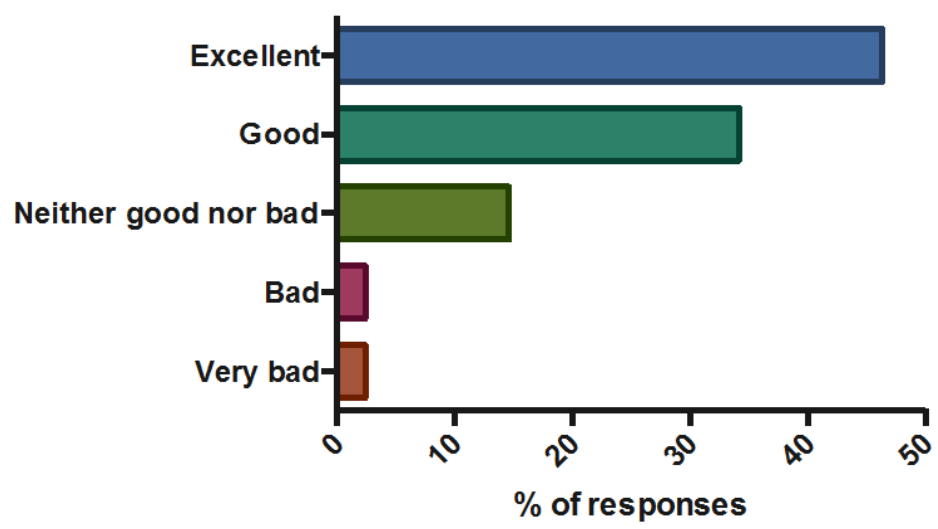

Figure 1: Rating of the flipped experience on a Likert scale

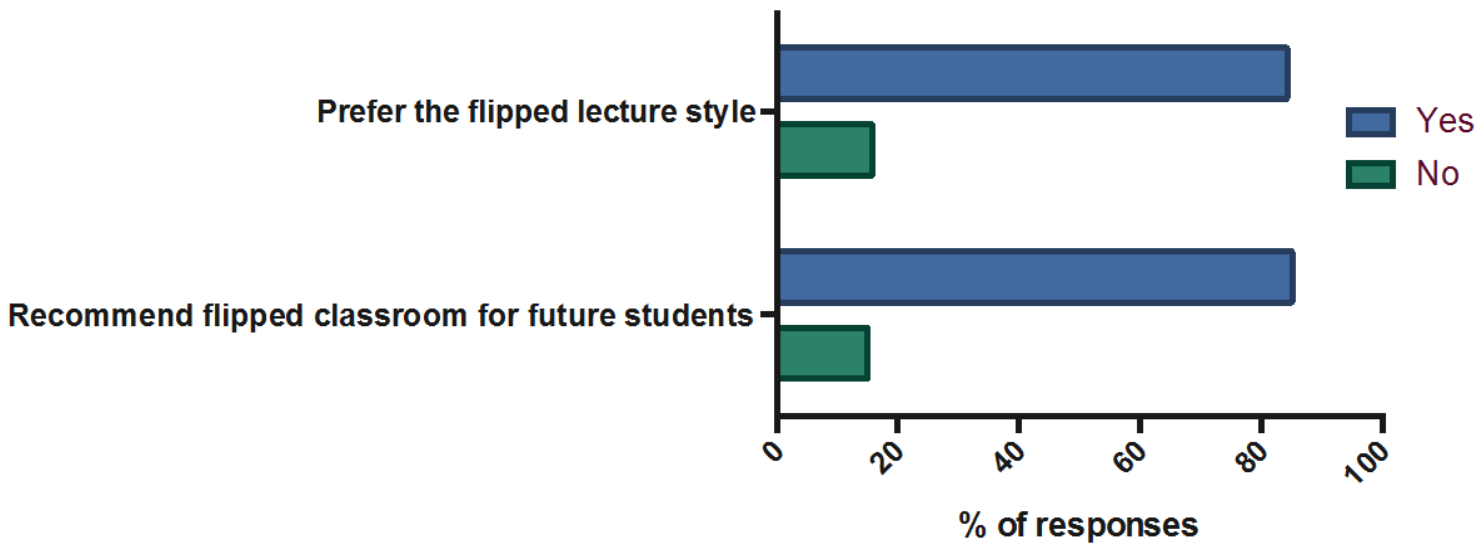

Figure 2: Preferred lecture style and recommendation for future students

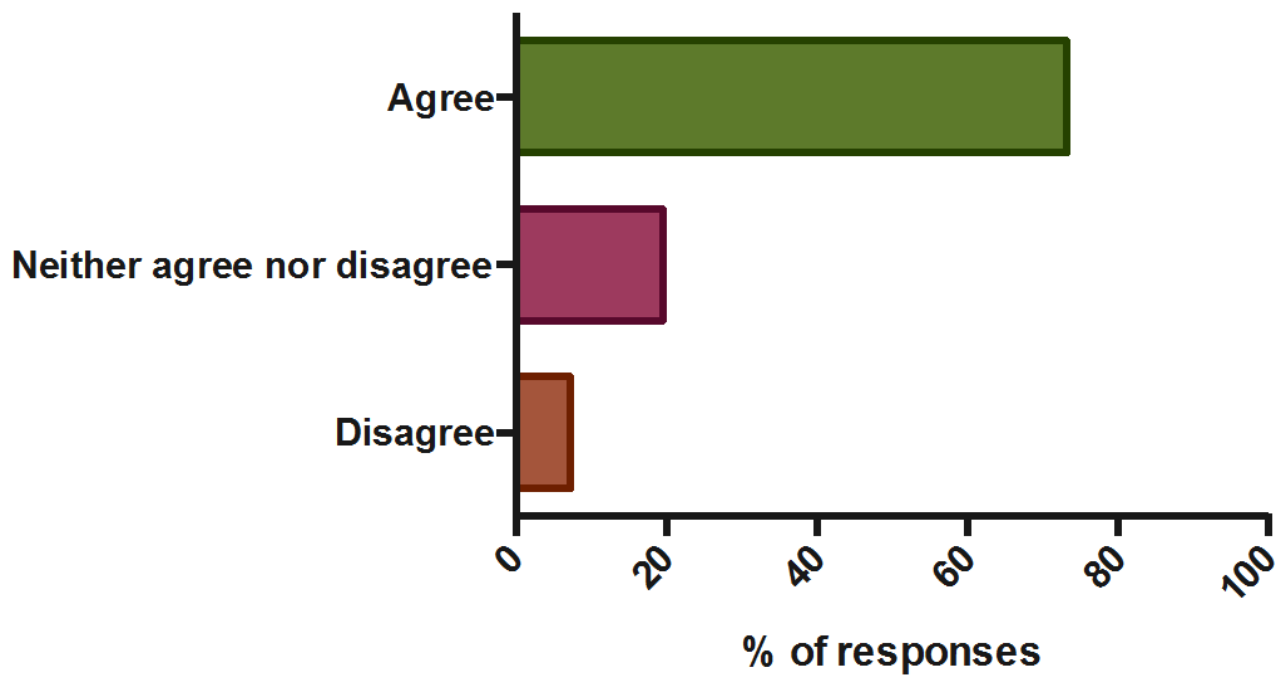

Figure 3: Eased understanding of the course content 


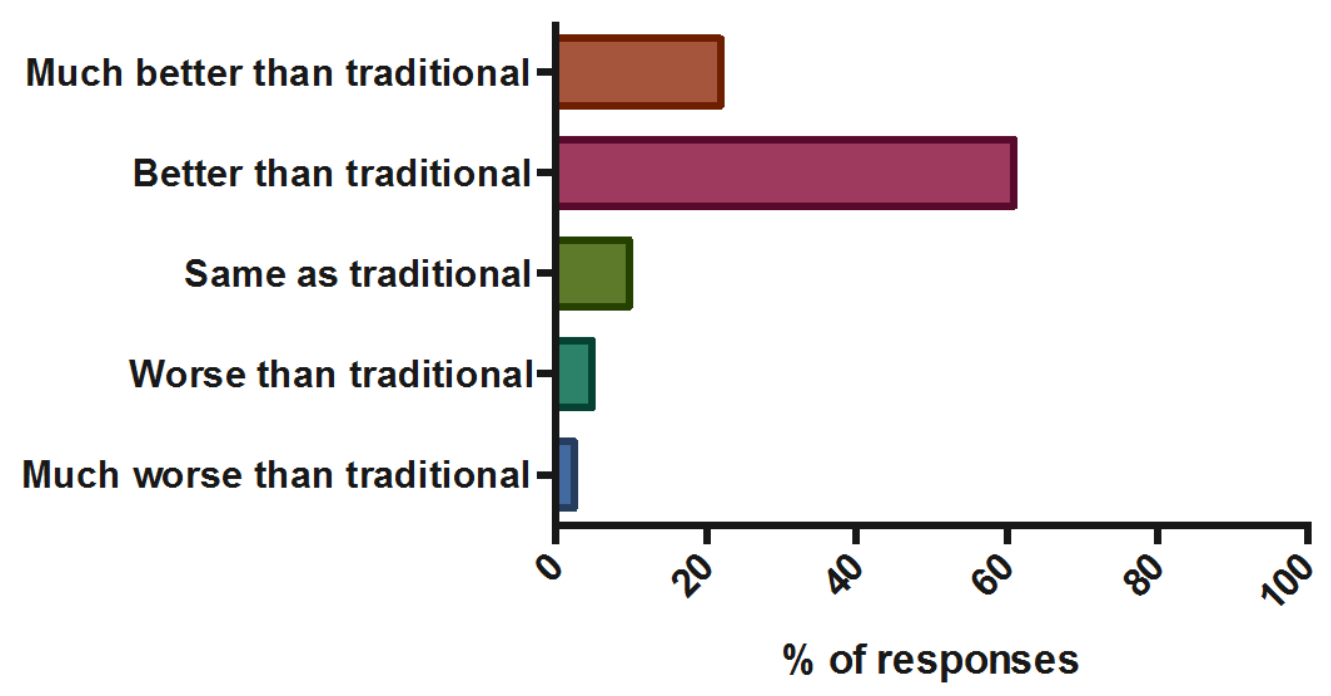

Figure 4: The flipped classroom's aid in learning the course content compared to traditional lectures.

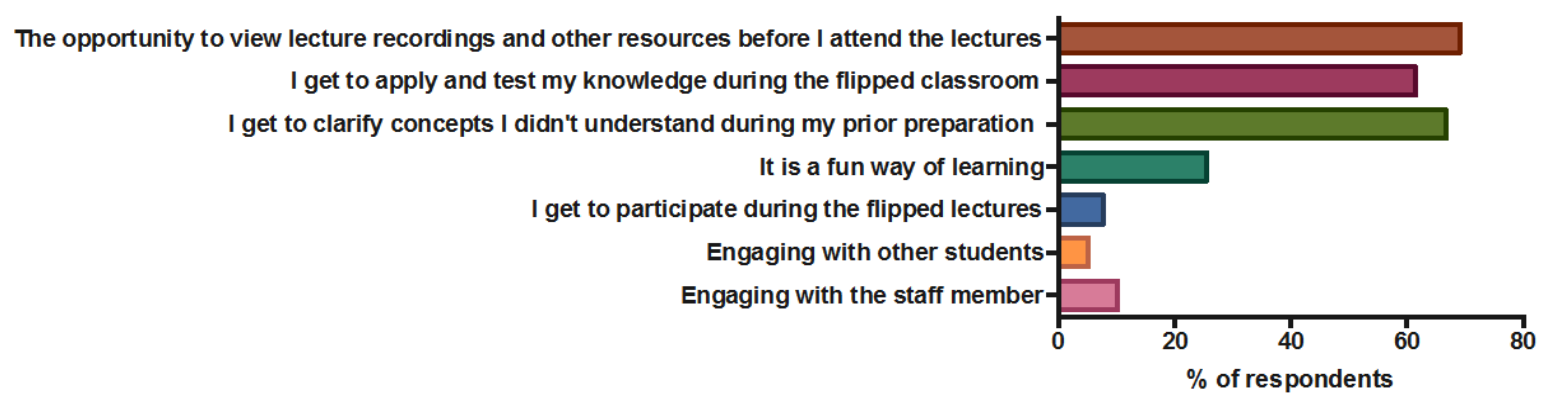

Figure 5: Further benefits of the flipped classroom

Students were queried also about how flipped classroom might be improved. Top on the list was the need for more time to prepare for the flipped classroom (38.46\%). Figure 6 summarises their responses.

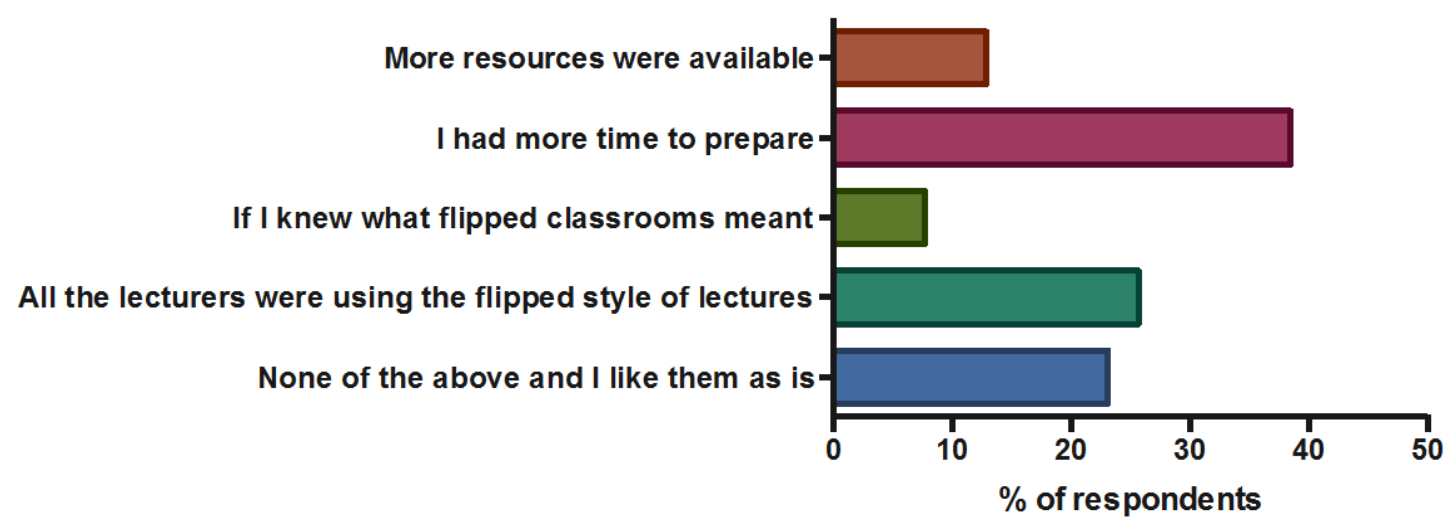

Figure 6: Possible improvements to the flipped classroom format. 


\section{Discussion}

The flipped classroom was applied to the Human Body course as one of the learning and teaching contexts to provide direct instruction, adjunct instruction, facilitate skills of learning, and widen learners' horizons. This study showed that it enables quality education opportunities that would be prohibitive due to time, travel, and cost constraints. The flipped classroom has applications for learning and teaching; it is a useful adjunct to traditional educational delivery modes.

Eighty-four percent (84\%) of the students surveyed preferred the flipped classroom for various reasons. The majority of students $(73.17 \%)$ found it easier to understand the course content utilising this approach. When invited to comment in the survey, students gave insight to how the approach facilitated understanding of content. It does this by allowing the student to "... learn the material first at my own pace", "reinforce the information", "reiterate the initial pre-lectures and notes", and "give[s] a student time to consolidate learning and content".

The students also touted the opportunity to listen to pre-recorded lectures, which they found very valuable. The students commented, "It just reinforces my own learning", "I get to look at it first, then go over it a second time to really let the message sink in", and "... it is a great way to make sure the ideas and information sticks". The other enhancements, the self-assessment quizzes in particular, that were designed to test knowledge and understanding were also beneficial. A student volunteered:

I do the reading and listen to the pre-recorded lectures. I do the quiz to test my understanding. These quizzes provide individual feedback. There is the opportunity to learn something twice.

As students become exposed to enhanced learning materials, they become more active in their learning (Kandies \& Stern, 1999). They ask questions and seek answers, explain concepts in ways they can connect and understand. These help them become self-directed learners.

Moreover, preference was given to the flipped classroom because it clarified difficult concepts before the class. The flipped classroom achieved the following: "A great way to learn especially if you are struggling with some of the concepts during the pre-recorded lecture", "makes more sense by the time you sit for a lecture", "... it helped explore the topic further enabling better understanding", "provides more explanations for my subject", "I learned the concepts a lot easier with the flipped lectures". This strategy and support were very important especially for a cohort that had little or no science background, were mature-aged, and/or belonged to families whose members have not participated in higher education.

The elements of fun and flexibility in learning could not be underestimated. The flipped classroom offered these to students, and they expressed this satisfaction in various ways:

For externals, it is fantastic to be able to listen a bit of information at the time when I have the time and great when each pre-recorded lecture is broken up into separate areas of that topic.

I really enjoyed them though.

I find it a better style of learning ... fun and easy to follow.

I like learning the content on my own time.

The approach guided students in using a variety of resources, encouraged them to develop clinical reasoning skills, supported students to connect with past experiences, and emphasised the need to be self-directed as well. A student commented, "It gives some responsibility for your own learning, coming into the lecture to reinforce what you already learned, not hear it for the first and then forgetting it 10 minutes later." Another student corroborated, "There is more op- 
portunity to think about the content better, to connect and make ownership of the learning." It can be seen that the flipped classroom format facilitates and enhances student responsibility in learning, and thus enhances the quality of learning in higher education (Davis \& Murrell, 1993).

The flipped classroom sessions provided opportunities for students to make judgments and get feedback about their learning. Thus $85 \%$ of those who responded recommended studying sciences in this manner. Their reasons included "Testing of knowledge to give direction to readings"; "More efficient learning"; "Helps overall understanding"; "Reiterates new learning"; "Valuable leaning experience that enables students to consolidate learning in a unique way"; "A good way to go back over to what you have learnt and ask questions"; "A great way to engage and gain a greater understanding of the information being received"; and "Enjoyable method of learning".

Sanders and Morrison-Shetlar (2002) and Wernet, Olliges, and Delicath (2000) support these findings. Web-enabled learning environments provide positive effects on student learning, problem-solving skills, and critical thinking skills and, thus, are beneficial to students' overall learning experience. Student critique of the flipped classroom was in the main positive. Specific suggestions offered by students to be considered in future offerings include "Lessen content of the slides", "Use of mouse rather than laser to point at things", and "Slow down the delivery of prerecordings". One student volunteered that the flipped classroom is more beneficial for internal students and "not much benefit for external students". Given the minimal interaction inherent with teacher(s) and peers in distance education, and the knowledge that student engagement enhances student success, this response to the flipped classroom is puzzling. Indeed, it is at odds with the majority of responses such as the following: "Flip all lectures", and "Incorporate a way by which students can participate more." It is possible that the flipped classroom was simply not the optimal teaching tool for the student's learning style. It may be necessary to deliver a blend of traditional and flipped lectures, to cater for the diverse modern cohorts (Buerck, Malmstrom, \& Peppers, 2003). Creating enough time to adequately engage in the flipped classroom was a concern: "With other subjects to consider it is very hard to watch pre-recorded lectures and do readings as well as the flipped lecture". While the flipped classroom may appear more time consuming to students, the time spent appears to deliver greater learning, engagement, satisfaction, and success in education and is therefore considered a superior method to traditional lectures.

The number of participants in the post-flip survey is small and this is a limitation. A bigger number of respondents would have been ideal to adequately represent the group. Greater survey participation is a goal of future iterations of the flipped classroom for external nursing students at our university.

\section{Conclusion}

It is important to examine the usage and preferences of flipping the classroom. This paper presented the findings of a small study on the flipped classroom, facilitated by electronic technologies and enhancements that determined the perceptions of students enrolled externally at an Australian university.

The results of the analysis indicated that students found that the approach enhanced the understanding of course content and that these had a beneficial impact on students learning experience. The examination of individual flipped classroom learning experiences indicated that students responded favourably to most of its features. Students overwhelmingly noted that they liked flipped classroom over traditional lectures. The reasons included that they were able to view prerecordings before lectures, apply and test knowledge, and clarify science concepts before flipped lectures.

Though constrained with a poor response rate, this study illustrated that the flipped classroom was a feasible learning and teaching approach for a science course, considering the desirable 
learning outcomes that were achieved. The creation of a carefully designed flipped classroom is central to a successful engagement.

\section{References}

Baker, C. (2012). Flipped classrooms: Turning learning upside down. Retrieved November 6, 2015, from http://www.deseretnews.com/article/765616415/Flipped-classrooms-Turning-learning-upsidedown.html

Barrett, D. (2012). How 'flipping' the classroom can improve the traditional lecture. Retrieved March 21, 2015, from https://people.ok.ubc.ca/cstother/How_Flipping the Classroom_Can_Improve the Traditional_Lectur e.pdf

Bergmann, J., \& Sams, A. (2012). Flip your classroom: Reach every student in every class every day. Washington, DC: Internal Society for Technology in Education.

Berner, R. T. (2004). Less is more: Designing an online course. DEOSNEWS, 13(4). Retrieved May 15, 2007, from http://www.ed.psu.edu/acsde/deos/deosnews/deosnews13 4.asp

Buerck, J. P., Malmstrom, T., \& Peppers, E. (2003). Learning environments and learning styles: Non- traditional student enrollment and success in an internet-based versus a lecture-based computer science course. Learning Environments Research, 6, 137-155. Retrieved December 15, 2015, from http://link.springer.com/artcle/10.1023/A:1024939002433\#/page-1

Buzzetto-More, N. (2008). Student perceptions of various e-learning components. Interdisciplinary Journal of E- Learning and Learning Objects, 4, 113-135. Retrieved January 4, 2016, from http://ijello.org/Volume4/IJELLOv4p113-135Buzzetto413.pdf

Cayetano-Penman, M., \& Ellis, B. (2007). Embracing technology in regional higher education. Collaboration for success in rural and remote education and training. In Proceedings of the, $23 \mathrm{rd}$ National Conference, 140-153.

Chen, Y., Wang, Y., Kinshuk, \& Chen, N. S. (2014). Is FLIP enough? Or should we use the FLIPPED model instead? Computers \& Education, 79, 16-27.

Connolly, T., \& Stansfield, M. (2007). Developing constructivist learning environments to enhance elearning. In N. Buzzetto-More (Ed), Principles of effective online teaching (pp. 19-38). Santa Rosa, CA: Informing Science Press.

Davis, T. M., \& Murrell, P. H. (1993). Turning teaching into learning: The role of student responsibility in the collegiate experience. Retrieved October 22, 2015, from http://www.tandfonline.com/doi/abs/10.1080/13538320500074915

Educause Learning Initiative. (2012). 7 things you should know about flipped classroom. Retrieved July 22, 2015, from http://net.educause.edu/ir/library/pdf/eli7081.pdf

Hamdan, N., McKnight, P., McKnight, K., \& Arfstrom, K. (2013). The flipped learning model: A white paper based on the literature review. Retrieved June 02, 2015, from http://researchnetwork.pearson.com/wp-content/uploads/WhitePaper_FlippedLearning.pdf

Jung, I. (2001). Building a theoretical framework of web-based instruction in the context of distance education. British Journal of Educational Technology, 32(5), 525-534.

Kandies, J., \& Stern, M. B. (1999). Weaving the Web into the classroom: An evolution of Web enhanced instruction. Paper presented at the Teacher Education International Conference, San Antonio, TX. (ERIC Document Reproduction Service No. ED 432270).

Kearsley, G., \& Shneiderman, B. (1998). Engagement theory: A framework for technology-based teaching and learning. Educational Technology, 38(5), 20-23.

Lee, P. (2007). The Teaching and Learning Framework, approved by Academic Board June 22, 2007. Adelaide: University of South Australia. 
Penman, J., \& Ellis, B. (2008). Virtual learning environments facilitating real learning in science courses. Teaching and Research: Making the connections in health sciences, 198-212.

Ramsden, P. (2003). Learning to teach in higher education (2nd ed.). London: Routledge.

Sanders, D., \& Morrison-Shetlar, A. (2002). Student attitudes toward web-enhanced instruction in an introductory biology course. Journal of Research on Computing in Education, 33(3), 251-262.

See, S., \& Conry, J.M. (2014). Flip my class! A faculty development demonstration of a flipped-classroom. ScienceDirect Currents in Pharmacy Teaching and Learning, 6, 585-588.

Singh, G., O’Donoghue, J., \& Worton, H. (2005). A study into the effects of eLearning on higher education. Journal of University Teaching \& Learning Practice, 2(1), 13-24.

Thalluri, J., \& Penman, J. (2015a). Social media for learning and teaching undergraduate sciences: Good practice guidelines from intervention. The Electronic Journal of e-Learning, 13(6), 455-465.

Thalluri, J. \& Penman, J. (2015b). Teaching/learning sciences to Nursing and Midwifery students: Experiences on flipped classroom style. (Manuscript submitted for publication December 2015.)

UniSA (2015). Learnonline, Retrieved September 23, 2015, from http://w3.unisa.edu.au/tel/learnonline/

UniSA Course Information (2015). Human body. Adelaide: University of South Australia.

Wernet, S., Olliges, R., \& Delicath, T. (2000). Postcourse evaluations of WebCT (Web Course Tools) classes by social work students. Research on Social Work Practice, 10(4), 487-504.

\section{Biographies}

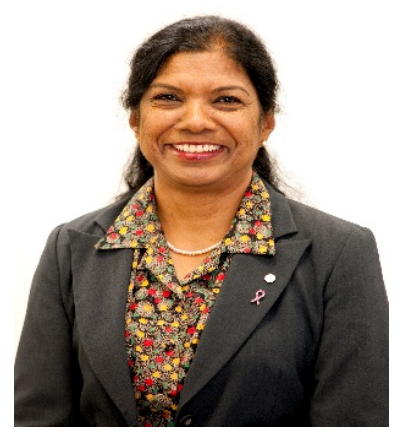

Dr Jyothi Thalluri is a Senior Lecturer and has extensive experience in 'service teaching' Human Anatomy/Physiology, Neurosciences and Pathology courses to various allied health science programs in the Division of Health Sciences, UniSA. Jyothi has a strong interest in the learning and teaching dynamics associated with student academic, social and cultural diversity. She has a strong belief that students need various learning options and appropriate support, particularly when transitioning into university study. She has demonstrated ongoing commitment in the implementation of a number of innovative initiatives, in order to engage, support and provide flexible and studentcentred learning options. She has used these to enhance outcomes within a diverse range of student cohorts. Jyothi has won many teaching awards and has published several papers in peer reviewed international teaching and learning journals.

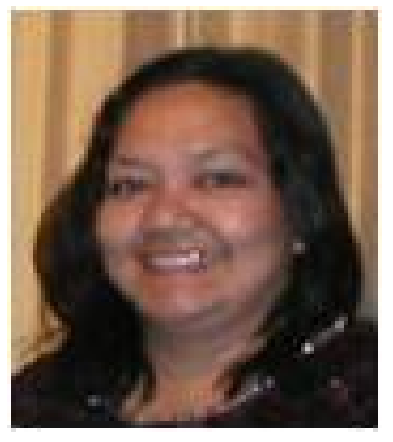

Dr Joy Penman holds bachelor and master's degrees in Nursing and Pharmacy. She completed her doctoral studies in palliative care. Joy teaches at the School of Nursing and Midwifery, Whyalla Campus. She has over thirty years teaching experience locally and abroad and many years nursing experience in various health care facilities. Joy has extensive experience in research and community engagement as well. In recognition of her contributions in these areas, she has been a recipient of various teaching, research and community service awards. Joy has received internal and external research funding for various collaborative projects. She is well published in peer reviewed and non-peer reviewed journals, conferences and books. 